\title{
Subklinik Hipotiroidi Nedir? Tedavi Edilmeli midir?
}

\author{
Özen ÖZ GÜL, Soner CANDER, Canan ERSOY
}

Uludağ Üniversitesi Tıp Fakültesi, Endokrinoloji ve Metabolizma Hastalıkları Bilim Dalı, Bursa.

\begin{abstract}
ÖZET
Bireylerin serum serbest tiroid hormon düzeyleri normal değerlerde iken tiroid uyarıcı hormon düzeyinin yüksek olması toplumda oldukça sık görülen bir durumdur ve bu durum subklinik hipotiroidi olarak tanımlanmaktadır. Subklinik hipotiroidi genel populasyonda \%3-8 oranında görülmekte, prevalansı yaşla birlikte artmakta ve kadınlarda daha sık görülmektedir. Subklinik hipotiroidinin en önemli sonucu aşikar hipotiroidiye ilerlemedir. Subklinik hipotiroidi ile kardiyovasküler hastalıklarda artış ve bilişsel fonksiyonlarda azalma arasındaki ilişki kesin olarak gösterilememiştir. Bu nedenle levotiroksin tedavisinin faydaları konusunda da fikir birliği bulunmamaktadır. Genel olarak tiroid uyarıcı hormon düzeyi $10 \mathrm{mU} / \mathrm{L}$ ’nin üzerinde olanlara tedavi önerilmekte, bu düzeylerin altında olanlarda tedavinin kişiselleştirilmesi, hastaların risk faktörleri ve yaşları göz önünde bulundurularak değerlendirilmeleri önerilmektedir.
\end{abstract}

Anahtar Sözcükler: Subklinik hipotiroidi. Tiroid fonksiyon testleri. Levotiroksin tedavisi.

What is Subclinical Hypothyroidism? Should it be treated?

\begin{abstract}
Although serum free thyroid hormone levels are normal, high levels of thyroid stimulating hormone is more frequent condition in population and is defined as subclinical hypothyroidism. In general population 3-8 \% is seen. Prevalance of subclinical hypothyroidism increases with age and is more common in women. Most important consequence of subclinical hypothyroidism is progression to overt hypothyroidism. increased risk of cardiovascular disease and a decreased cognitive functions due to subclinical hypothyroidism remains uncertain. Therefore, the consensus about the benefits of levothyroxine treatment is not available. In general, the level of thyroid stimulating hormone 10 mU/L, those on treatment are recommended, which are below the level of treatment to be personalized, consideration of patient age, risk factors are recommended.
\end{abstract}

Key Words: Subclinical hypothyroidism. Thyroid function tests. Levothyroxine treatment.

Subklinik hipotiroidi, serum serbest tiroid hormon düzeyleri normal değerlerde olduğu halde tiroid uyar1cı hormon (TSH) düzeyinin yüksek olması ile karakterizedir $^{1}$. Subklinik hipotiroidi biyokimyasal bir tanımlamadır, dolayısıyla hastalar asemptomatik olabilirler ya da non-spesifik semptomları olabilir. Tiroid hastalıklarında görülen semptomları sorgulayarak subklinik tiroid hastalıklarını tespit etmek zordur. Hipotiroidi için bazı klinik skorlama sistemlerinin (Düşük bazal metabolik hız, uykuda kalp hızındaki azalma, total kolesterol artışı, LDL-kolesterol ve Lipoprotein-a artışı, aşil refleks zamanında gecikme, kreatinin kinaz artışı, miyoglobin artışı gibi) kullanılması objektif

Geliş Tarihi: 21 Haziran 2018

Kabul Tarihi: 02 Temmuz 2018

Dr. Özen ÖZ GÜL

Uludağ Üniversitesi Tıp Fakültesi,

Endokrinoloji ve Metabolizma Hastalıkları Bilim Dalı,

Görükle, Bursa

Tel.: 02242951140

E-posta: drozenoz@gmail.com değerlendirmeyi sağlasa da bu sistemlerin klinik kullanımının zorluğu nedeniyle önerilmemektedir. Genellikle TSH 10-12 mU/L düzeylerine kadar semptom görülmemektedir. Subklinik hipotiroidi tanımlaması yapılırken TSH üst sınır değeri önem kazanmaktadır. TSH'ın alt sınırı rölatif olarak daha iyi belirlenmişken, üst sınırı konusunda farklı görüşler mevcuttur. Genel kabul gören değerler, 0.4-5.5 mU/mL ve 0.27-4.2 uU/mL'dir. Türkiye Endokrinoloji ve Metabolizma Derneğinin (TEMD) önerisi, TSH'ın normal aralıklarının 0.5-4 mU/L olmasıdır ${ }^{2}$. Çeşitli dernek ve çalışmalarda önerilen TSH üst sınır değerleri Tablo I'de özetlenmiştir. Tiroid hastalığı olmayan ve anti tiroidperoksidaz (anti TPO) antikoru negatif bulunan 13344 bireyin değerlendirildiği NHANES III çalışmasında ortalama TSH değeri $1.49 \pm 0.04 \mathrm{mU} / \mathrm{L}$ olarak saptanmıştır ${ }^{3}$. Amerikan Tiroid Birliği (ATA), Amerikan Klinik Endokrinologlar Birliği (AACE), Amerikan Endokrin Birliği (Endocrine Society), NHANES III'te belirlenen aralıkları önermektedirler ${ }^{4-6}$. TSH üst sınırı önemlidir çünkü TSH üst sınırının 5'ten $2.5 \mathrm{mU} / \mathrm{L}$ 'e 


\section{Ö.Ö. Gül, ark.}

azaltılması subklinik n1 \%4,6'dan \%20'ye yükseltmektedir ${ }^{7}$.

Tablo I. Uluslararası çeşitli çalıșma ve derneklerce önerilen TSH üst sınır değerleri

\begin{tabular}{|c|c|c|}
\hline Grup & TSH üst sınırı & Açıklama \\
\hline NACB & $2.5 \mathrm{mU} / \mathrm{L}$ & Tiroid hastalığı yok \\
\hline $\begin{array}{l}\text { NHANES III, hastalık } \\
\text { yok }\end{array}$ & $4.5 \mathrm{mU} / \mathrm{L}$ & Tiroid hastalığı yok \\
\hline $\begin{array}{l}\text { NHANES III, referans } \\
\text { populasyon }\end{array}$ & $4.12 \mathrm{mU} / \mathrm{L}$ & $\begin{array}{l}\text { Tiroid hastalığı yok, } \\
\text { antikor (-), tiroid fonksiyon } \\
\text { testlerini etkileyecek ilaç } \\
\text { yok }\end{array}$ \\
\hline $\begin{array}{l}\text { Hanford Tiroid Çalış- } \\
\text { ma Grubu }\end{array}$ & $4.1 \mathrm{mU} / \mathrm{L}$ & $\begin{array}{l}\text { Tiroid hastalığı yok, } \\
\text { antikor(-), tiroid ilacı yok, } \\
\text { USG normal }\end{array}$ \\
\hline $\begin{array}{l}\text { NHANES III, 20-29 } \\
\text { yaş, Afrikan-Amerikan }\end{array}$ & $3.6 \mathrm{mU} / \mathrm{L}$ & \\
\hline NHANES III, $\geq 80$ yaş & $7.8 \mathrm{mU} / \mathrm{L}$ & Tiroid hastalığı yok \\
\hline TEMD 2013 & $4 \mathrm{mU} / \mathrm{L}$ & Tiroid hastalığı yok \\
\hline
\end{tabular}

NACB: The National Academy of Clinical Biochemists; NHANES: National Health and Nutrition Examination Survey

Subklinik hipotiroidi saptandığında TSH'ın zaman içinde değişkenlik gösterebileceği akılda tutulmalıdır. Ilımlı anormal TSH düzeyi saptanan hastalarda, 1-3 ay sonra test tekrarlanmalı, kalıcı yükseklik doğrulanma$11 d_{12}^{2}$. Geçici yükselmelerin olabileceğigöz önünde bulundurulmalıdır. Ayrıca serum TSH düzeyleri gün içinde de değişkenlik göstermektedir. TSH öğleden sonra geç dönemde en düşük düzeyde olup, uykunun başlamasını takiben yükselmektedir. Ancak bu değişiklikler çoğunlukla normal sınırlarda kalmaktadır. TSH ölçümünün 08:00-17:00 saatleri arasında yapılması, levotiroksin kullananlarda tetkik öncesi ilaç alınmaması veya ilaç alımından en az 8 saat geçmiş olması gerekmektedir. TSH $20 \mathrm{mU} / \mathrm{L}$ düzeylerine kadar yükseldiği halde tiroid hormonları normal düzeylerde saptanabilir. TSH yüksekliği şu durumlarda subklinik hipotiroidi ile ilişkili değildir: Hasta ötiroid sendromun iyileşme dönemi, adrenal yetmezlik, metoklopramid ve domperidon kullanımı, TSH sekrete eden adenom, tiroid hormon direnci sendromu ve analiz (ölçüm) hataları. Hastayı değerlendirirken bu faktörler göz önünde bulundurulmalı, ayırıcı tanı uygun şekilde yapılmalıdır.

\section{Epidemiyoloji}

TSH üst sınırının $10 \mathrm{mU} / \mathrm{L}$ olarak alındığ 1 Whickham çalışmasında; prevalans erkeklerde \% 2.8, kadınlarda \%7.5, 60 yaş üstü kadınlarda \%11.6 olarak saptanmıştır ${ }^{8}$. Tiroid hastalık öyküsü olanlarınçalışma dışı bırakılıp TSH üst sınırının $4.5 \mathrm{mU} / \mathrm{L}$ olarak alındığ NHANES III çalışmasında subklinik hipotiroidi pre- valansı \%4.3 olarak saptanmıştır ${ }^{9}$. Bu çalışmada prevelansın yaşla arttığı, kadınlarda ve beyazlarda daha yüksek olduğu gösterilmiştir. Avrupa’da iyot eksikliği olan bölgelerde subklinik hipotiroidi prevalansı daha düşüktür. AntiTPO düzeyleri benzer olup iyot alımı yetersiz olanlarda subklinik hipotiroidi prevalans1 \%4.2 iken, iyot alımı yeterli olanlarda \%23.9 olduğu bildirilmektedir ${ }^{10}$. Colorado Tiroid Hastalıkları Prevelans Çalışmasında (n: 25862), TSH üst sınır $5 \mathrm{mU} / \mathrm{L}$ olarak alınmış; toplam subklinik hipotiroidi prevalansı \%9.5, 18-24 yaş arası bireylerde \%4.0, 74 yaş üstü kadınlarda \%22, 74 yaş üstü erkeklerde \%16 olduğu görülmüştür ${ }^{10}$. Tip 1 diabetes mellitus, Schmidt's sendromu, çölyak hastalığı gibi bazı otoimmun hastalıklarla prevelansın arttığ 1 bildirilmektedir. Bunun nedeninin otoimmun hastalıklara eşlik eden Hashimoto tiroiditi varlığı olduğu düşünülmektedir.

\section{Etyoloji}

Subklinik hipotiroidi nedenleri aşikar hipotiroidi nedenleri ile aynıdır. En sık görülen nedeni Hashimoto tiroiditidir. Subklinik hipotiroidisi olan hastaların \%54'ünde tiroid otoantikorlarının pozitif olduğu bildirilmektedir ${ }^{11}$. İngiltere'de yapılan bir çalışmada Subklinik hipotiroidisi olan kadınların \%67'sinde, erkeklerin \%40'ında otoantikorların pozitif olduğu görülmüştür ${ }^{12}$. Diğer s1k görülen neden aşikar hipotiroidi nedeniyle levotiroksin kullanan hastaların ilaçlarını uygun şekilde kullanmamaları ve hastalık uyumlarının kötü olmasıdır. Postpartum tiroidit de subklinik hipotiroidi nedenlerinden biridir. Postpartum tiroidit gebelik öncesi bilinen tiroid hastalığı olmayan kadınlarda doğum sonrasını takip eden ilk 1 yıl içinde izlenen tiroid inflamasyonu ile karakterize klinik durumdur. Seyir değişkenlik göstermekle beraber genellikle şöyledir: geçici hipertiroidi (1-2 ay), geçici hipotiroidi (4-6 ay), 1.yılın sonunda vakaların \%80'inde ötiroidi izlenmektedir ${ }^{13}$. Uzun dönemde ise vakaların \%2064'ünde kalıcı hipotiroidi gelişebilmektedir. Bu nedenle yılda bir kez TSH ölçülmesi önerilmektedir. Kullanılan bazı ilaçlar da tiroid hormonlarını farklı mekanizmalarla etkileyerek subklinik hipotiroidiye neden olabilmektedir. Amiadoron iyotun tiroid hücrelerince alınmasını (uptake) ve hormon üretimini azaltarak, yine tiroid hormonlarının periferal metabolizmasını etkileyerek, lityum tiroid hormon sekresyonunu azaltarak ve tiroidit yaparak, interferon, sunitinib ve sorafenib tiroidit yaparak hipotiroidi veya subklinik hipotiroidiye neden olmaktadirlar. Parsiyel tiroidektomi vebaş-boyun bölgesine uygulanan radyoterapi sonrası da subklinik hipotiroidi gelişebilmektedir. Graves hastalığında medikal tedavi veya radyoablasyon uygulaması sonrasında da subklinik hipotiroidi gelişebilmektedir. 


\section{Subklinik Hipotiroidi}

\section{Tarama}

Subklinik hipotiroidi nedeniyle kimlerin taranması gerektiği konusunda fikir birliği sağlanamamıştır. Bazı araştırmacılar veya dernekler tarafından subklinik hipotiroidi sık görüldüğü ve özellikle yaşlı kadın hastalarda tedavisi önemli olduğundan tarama yapılması önerilirken, diğerleri ise gebelik ve infertilite dışında subklinik hipotiroidi tedavisinin yararı net olmadığından taramanın gereksiz olduğunu öne sürmektedir ${ }^{14-16}$ (Tablo II). TEMD 35 yaş üstü kişilerde her 5 yılda bir tarama yapılmasını önermektedir².

Tablo II: Subklinik hipotiroidi tanısı için uluslararası çeşitli derneklerin tarama önerileri

\begin{tabular}{|c|c|}
\hline Grup & Tarama Önerileri \\
\hline $\begin{array}{l}\text { American Thyroid Association } \\
\text { (ATA) }\end{array}$ & $>35$ yaş kişilerde 5 yılda bir \\
\hline $\begin{array}{l}\text { American Association of Clinical } \\
\text { Endocrinologists (AACE) }\end{array}$ & $\begin{array}{l}\text { Özellikle yaşlı kadınlar (yaş } \\
\text { belirtilmemiş) }\end{array}$ \\
\hline $\begin{array}{l}\text { American Academy of Family } \\
\text { Physicians }\end{array}$ & $\geq 60$ yaş kişiler \\
\hline American College of Physicians & $\begin{array}{l}\text { Tiroid hastalığını düşündüre- } \\
\text { cek semptom veya bulguları } \\
\text { olan } \geq 50 \text { yaş kadınlar }\end{array}$ \\
\hline $\begin{array}{l}\text { US Preventive Services Task } \\
\text { Force }\end{array}$ & $\begin{array}{l}\text { Tarama yapılıp-yapılmaması } \\
\text { konusunda yeterli kanıt yok }\end{array}$ \\
\hline $\begin{array}{l}\text { Royal College of Physicians of } \\
\text { London }\end{array}$ & $\begin{array}{l}\text { Sağlıklı yetişkinlerin taranması } \\
\text { konusunda yeterli kanıt yok. }\end{array}$ \\
\hline $\begin{array}{l}\text { Consensus Panel (ATA, AACE, } \\
\text { Endocrine Society) }\end{array}$ & $\begin{array}{l}\text { Tarama yapılıp-yapılmaması } \\
\text { konusunda yeterli kanıt yok }\end{array}$ \\
\hline
\end{tabular}

\section{Tanı/Antikor Ölçümü}

Tanı biyokimyasal olarak konulmaktadır. Tiroid hormonları normal olduğu halde TSH düzeyinin yüksek olması ile subklinik hipotiroidi tanısı konulmaktadır. Rutin olarak tüm subklinik hipotiroidisi olan hastalarda tiroid otoantikor düzeylerinin bakılması önerilmemektedir. Ancak tedavi veya izlem kararı verilecek olan hastalarda bakılması önerilmektedir. Tiroid otoantikor varlığında subklinik hipotiroididen aşikar hipotiroidiye ilerleme riski daha yüksektir. Anti TPO antikor düzeyi yüksek saptanan hastalarda aşikar hipotiroidiye ilerleme y1llık \%4.3 iken, yüksek saptanmayanlarda ise bu risk yıllık \%2.6 olarak bildirilmiştir ${ }^{8,17}$. $\mathrm{Bu}$ nedenle AACE, subklinik hipotiroidide antikor bakılmasını önermektedir ${ }^{5}$.

\section{Subklinik hipotiroidi neden önemlidir?}

Subklinik hipotiroidi, aşikar hipotiroidiye ilerleyebileceğinden, kardiyovasküler sistem, fertilite, yaşam kalitesi, depresyon, kognitif fonksiyonlar üzerine olumsuz etkileri olması nedeniyle önemlidir.

Aşikar Hipotiroidiye Illerleme: Subklinik hipotiroidide yıllık \%2-5 oranında aşikar hipotiroidiye ilerleme mevcuttur ${ }^{8}$. Uzun süreli izlemlerde \%10 normale dönüş tespit edilmiştir. Başlangıç TSH düzeyi (TSH>12-15 mU/L) ne kadar yüksekse ve antikor pozitifliği mevcutsa ilerleme riski o kadar fazladır ${ }^{18}$. Altta yatan tiroid hastalığı aşikar hipotiroidiye ilerlemeyi ön görmede önemli faktörlerden biridir. Otoimmun tiroid hastalığı, radyoablasyon tedavisi, yüksek doz eksternal radyoterapi almış olanlarda ilerleme riski daha yüksektir. Subklinik hipotiroidide kendiliğinden iyileşmeler de görülebilmektedir. Daha öncesine ait tiroid hastalık öyküsü olmayan 422242 hastanın dahil edildiği bir çalışmada TSH düzeyi 5.5-10 mU/L arasında olan hasta oranı $\% 3$ olarak saptanırken, bu hasta gurubunda tedavi verilmeksizin 5 y1llı izlemde TSH düzeyinin normale dönme oranının \%62 olduğu saptanmıştır $^{19}$. Bu çalışmada da görülmektedir ki TSH düzeyinin normale dönme ihtimali azımsanmayacak düzeydedir. Whickham çalışmasında (n:25900) hastalar 20 yıl süre ile takip edilmişler; başlangıç TSH düzeyi normal ve antikor pozitif olanların $\% 27$ 'sinde, TSH düzeyi normalden yüksek olanların \%33’ünde, TSH düzeyi yüksek ve antikor pozitif olanların \%55'inde, TSH düzeyi normal ve antikor negatif olanların \%4'ünde aşikar hipotiroidi gelişmiştir ${ }^{8}$. Bu sonuçlar TSH düzeyi ile antikor pozitifliğinin aşikar hipotiroidiye progresyon riskinin en önemli belirleyicileri olduğunu göstermektedir.

Kardiyovasküler Sistem Üzerine Olan Etkileri: Subklinik hipotiroidide aşikar hipotiroidi de olduğu gibi diyastolik disfonksiyon, diyastolik hipertansiyon, LDL-kolesterol yüksekliği, high-sensitivity c-reaktif protein (hsCRP) yüksekliği, koagülasyon parametrelerinde değişiklik, endotelyal disfonksiyon ortaya çıkabilmektedir $^{18}$. Whickham çalışmasında subklinik hipotiroidisi olan hastaların 20 yıllık izlemlerinde koroner arter hastalığı, dislipidemi, mortalite arasında ilişki saptanmamıştır ${ }^{8}$. Öte yandan Rotterdam çalışmasında subklinik hipotiroidi olan kadınlarda ateroskleroz riski $1.7 \mathrm{kez}$, miyokard infarktüsü (MI) riski ise $2.3 \mathrm{kez}$ daha yüksek bulunmuştur ${ }^{20}$. Yedi prospektif çalışmanın incelendiği bir metaanalizde, 25977 katılımcı ve 2020 subklinik hipotiroidi hastasının değerlendirme sonuçlarına göre TSH artışı ile kardiyovasküler hastalıklarda (ölümcül olmayan MI, kardiyovasküler hastalık (KVH) nedenli ölüm, anjina veya koroner revaskülarizasyon nedeniyle hospitalizasyon) artış saptanmış$\operatorname{tır}^{21}$. Ötiroidik kişilerle karşılaştırıldığında $\mathrm{TSH}>10 \mathrm{mU} / \mathrm{L}$ olanlarda KVH riski artarken (38.4'e karşılık 20.3 olay/1000 hastalık yılı), minimal TSH artışlarında (4.5-6.9 mU/L) bu risk artışı saptanmamıştır. Risk yaş, cinsiyet veya KVH öyküsü ile düzeltildiğinde de değişmemiştir. Altı prospektif çalışmanın incelendiği ve 25390 katılımc1, 2068 subklinik hipotiroidili hastayı içeren başka bir metaanalizde yükselen TSH ile kalp yetmezliği riskinde artış olduğu saptanmıştır ${ }^{22}$. Ötiroidik kontrol grubuyla karşılaştırıldığında TSH 10-19.9 mU/L olanlarda kalp yetmezliğinde anlamlı artış saptanmışken (224 kişide 40 olay 
(\%17.9) / 22674, kontrol grubunda 1762 olay (\%7.8)), TSH'ın daha 1lımlı artışlarında kalp yetmezliği riskinde artış saptanmamıştır. Çalışmalarda ki sonuçların çelişkiliolduğu görülmektedir. Bunun sebebi çalışmaya alınan hasta sayısı çok iken subklinik hipotiroidisi olan hasta sayısının az olması (örnek: 4331 hasta ancak subklinik hipotiroidi 281) ve çalışmaların tasarımlarının farklı olmasıdır.

Fertilite Üzerine Etkileri: Subklinik hipotiroidisi olan kadınlarda gebelik ve doğum ile ilişkili risklerde artış mevcuttur. Anti Tg ve Anti TPO antikoru pozitif olan kadınlarda spontan düşük oranı \%17 iken antikor negatif olanlarda \%8.4 tür $^{23}$. Doğumla ilișkili risklerin değerlendirildiği bir çalışmada, 25756 gebede subklinik hipotiroidi oranı \%2.3 saptanmış, plasental ablasyo ve preterm olay riski normale göre 2 kat yüksek olarak bulunmuştur ${ }^{24}$. Tanı ve tedavi uygulanmamış subklinik hipotiroidisi olan gebelerde abortus, düşük doğum ağırlıklı bebek, gelişim geriliği riskleri artmış bulunmuştur.

Nöropsikiyatrik Hastallklar Üzerine Etkileri: Subklinik hipotiroidisi olanlarda tüm hayatları boyunca depresyon prevelansı daha fazla bildirilmektedir ${ }^{25}$. Subklinik hipotiroidisi ve guatrı olan kadınlarda anksiyete ve depresif yakınmalar daha fazla görülmektedir. Subklinik hipotiroidi ile birlikte depresyonu olanlarda antidepresan tedaviye yanıtın daha zayıf olduğu saptanmıştır ${ }^{26}$. Öte yandan birçok çalışmada ise subklinik hipotiroidi ile depresyon, anksiyete ve kognitif disfonksiyon arasında ilişki gösterilememiștir ${ }^{27}$.

Non-Alkolik Karaciğer Hastalı̆̆ (NAKH) Üzerine Etkileri: Subklinik hipotiroidide aterojenik lipid profili oluşmakta, koagülasyon faktörlerinde oluşan değişikliklerle hepatosteatoza eğilim oluşmakta mıdır düşüncesinden yola çıkılarak yapılan bir çalışmada, NAKH ile serum TSH düzeyleri arasında korelasyon saptanmıştır ${ }^{28}$. Subklinik hipotiroidisi olan hastaların \%30'unda, aşikar hipotiroidisi olan hastaların \%36'sında NAKH tipik USG bulguları saptanmıştır (kontrol grubunda \%20) ${ }^{28}$. Ayrica subklinik hipotiroidi olan hastaların \%20'sinde, aşikar hipotiroidisi olan hastaların \%26'sında anormal karaciğer enzim düzeyleri olduğu görülmüştür.

Mortalite Üzerine Etkileri: Onbir çalışmanın değerlendirildiği bir metaanalizde TSH $>10 \mathrm{mU} / \mathrm{L}$ olduğunda kardiyovasküler mortalite riskinin arttığı saptanmış$\mathrm{tır}^{21}$. Ancak TSH'ın minimal artışlarında $(4.5 \mathrm{mU} / \mathrm{L}-$ $6.9 \mathrm{mU} / \mathrm{L}$ ) kardiyovasküler ve total mortalite riskinde değişiklik saptanmamıştır ${ }^{21}$. Tedavi edilmemiş yaşlı subklinik hipotiroidi olan hastalarda mortalitede artıs veya azalış gösterilememiştir ${ }^{29}$.

Diğer Etkileri: Bazı çalışmalarda TSH düzeyinin normal sınırlarda artışı ile 1lımlı kilo artışı arasında ilişki saptanmış, ancak birçok çalışmada obezite ile subklinik hipotiroidi arasında ilişki bulunmamıştır ${ }^{30,31}$. Populasyon bazlı bir çalışmada subklinik hipotiroidisi olan kadınlarda Alzheimer hastalık riskinin artmıs olduğu saptanmıștır ${ }^{32}$. Subklinik hipotiroidisi olanlarda kolelityazis daha sık görülmektedir ${ }^{33}$. Bunun da oddi sfinkter disfonksiyonu nedeniyle olduğu düşünülmektedir. Demir eksikliği anemisi ve Subklinik hipotiroidisi olan kişilerde, demir preparatları ile birlikte tiroid hormonu tedavisi verilmesi hemoglobinde daha belirgin bir artışı sağlamaktadır ${ }^{34}$.

\section{Subklinik hipotiroidi neden tedavi edilmelidir?}

Tedavinin potansiyel faydaları; aşikar hipotiroidiye ilerlemenin önlenmesi, kardiyovasküler nedenlere bağlı ölüm riskinde artışa yol açan serum lipid profili üzerine olumlu etki, psikiyatrik ve kognitif bozukluklardaki semptomların azalmasıdır. Dolayısıyla başta yaşam kalitesi olmak üzere yaşam süresinin uzatılması amaçlanmaktadır.

\section{Subklinik hipotiroidi tedavisinin etkileri}

Subklinik hipotiroidide tedavi verilmesinin faydaları konusunda çalışma sonuçları farklıdır. Çift kör randomize çalışmalarda tedavi ile, psikometrik değerlendirmeler ve hipotiroidi semptom skorlarının TSH $>10$ $\mathrm{mU} / \mathrm{L}$ olanlarda iyileşme sağladığı, bu değerlerin altında olan subklinik hipotiroidide değişiklik yapmadığ bildirilmiştir $^{35,36}$. Levotiroksin tedavisi ile total kolesterol düzeyi ve LDL-kolesterolde azalma olduğu saptanmıştır ${ }^{37}$. Oniki çalışmanın incelendiği bir analizde ise total kolesterol, HDL-kolesterol, LDLkolesterol, trigliserid, apolipoprotein A ve B, lipoprotein-a düzeylerinde değişiklik olmamıştır ${ }^{38}$. Levotiroksin tedavisi ile kardiyak output'ta artış, vasküler rezistansta azalma, ortalama arteryal basınçta azalma, karotis intima media kalınlığında azalma, diyastolik ve sistolik fonksiyonlarda iyileşme sağlanırken, $>70$ yaş olanlarda tedavi etkinliği gösterilememiştir ${ }^{18}$.

\section{Kimler tedavi edilmelidir?}

Subklinik hipotiroidisi olan hastalarda TSH $>10 \mathrm{mU} / \mathrm{L}$ ise levotiroksin tedavisi önerilmektedir ${ }^{15}$. TSH 4.5-10 $\mathrm{mU} / \mathrm{L}$ olanlara rutin tedavi önerilmemekle birlikte, 612 ayda bir takip önerilmektedir. Gebelerde, gebelik planı olanlarda, anovulasyonu veya infertilitesi olanlarda $\mathrm{TSH}>2.5 \mathrm{mU} / \mathrm{L}$ ise tedavi verilmesi gerekmekte$\mathrm{dir}^{4-6} .65$ yaş altı ve TSH $4.5-10 \mathrm{mU} / \mathrm{L}$ olanlarda antikor yüksekliği, eşlik eden guatr veya belirgin semptomatik hastalarda tedavi gerekli olmaktadır. TEMD, TSH $>10 \mathrm{mU} / \mathrm{L}$ olan tüm hastalarda, TSH 4-10 mU/L arasında ise; guatr, tiroid otoantikor pozitifliği (Anti TPO ve/veya Anti-TG), TSH'in giderek artması, TSH'ın 2 kez 8 mU/L ve üzerinde bulunması, bipolar duygu durum bozukluğu durumlarından birinin varl1ğında tedavi önermektedir ${ }^{2}$. 


\section{Subklinik Hipotiroidi}

\section{Tedavi}

Tedavide levotiroksin tercih edilmelidir. Subklinik hipotiroidide 25-75 mcg/gün dozları genellikle yeterli olmaktadır. Başlangıç levotiroksin dozu $25 \mathrm{mcg} /$ gün alınıp hedef TSH düzeyine ulaşılana kadar 4-8 haftalık aralıklarla doz arttırılması önerilmektedir ${ }^{4}$. Yaşa uygun TSH üst sınırı hedef TSH düzeyi belirlenirken dikkate alınmalıdır. Hedeflenen TSH değerine ulaşıldiktan sonra 6-12 aylık dönemler ile kontrol edilmelidir.

Tedavi de amaç TSH düzeyinin normal aralıklarda tutulmasıdır ${ }^{4,5}$. TEMD tedavi ile TSH düzeyinin, risk taşımayan gençlerde $0.5-2.5 \mathrm{mU} / \mathrm{L}$; kardiyovasküler riski yüksek, ileri osteoporozu olanlarda, atriyal fibrilasyon varlığında 1-4 mU/L olarak hedeflenmesini önermektedir ${ }^{2}$. TSH üst sınırı 70-79 yaş için $6 \mathrm{mU} / \mathrm{L}$; >80 yaş için 7.5mU/L olduğu hatırlanmalı, replasman dozu ayarlanırken bu değerler göz önünde bulundurulmalıdır².

\section{Sonuç}

Subklinik hipotiroidi toplumda oldukça sık görülen bir durumdur. Özellikle yaşla prevelans artmakta, 60 yaş üstü kişilerde \%20 düzeylerine ulaşmaktadır. Sik görülmesi nedeniyle toplum taraması yapılması konusunda fikir birliği bulunmamakla birlikte, 35 yaş üstü kişilerde 5 yılda bir yapılması önerilmektedir. Subklinik hipotiroidide tedavi veya izlem kararı verilecek olan hastalarda antikor bakılması önerilmektedir. Antikor pozitifliği aşikar hipotiroidiye progresyonu göstermesi bakımından önemlidir. Subklinik hipotiroidi, aşikar hipotiroidiye ilerleyebileceği gibi bazı olumsuz klinik etkileri de ortaya çıabilmektedir. $\mathrm{TSH}>10 \mathrm{mU} / \mathrm{L}$ olan kişilerde tedavi verilmesi önerilmekte iken $\mathrm{TSH}<10 \mathrm{mU} / \mathrm{L}$ olanlarda hastanın yaşı, eşlik eden hastalıkları, risk faktörleri göz önünde bulundurularak tedavi kararı verilmelidir. Aşikar hipotiroidi de olduğu gibi tedavi hayat boyu devam edeceğinden hasta bu konuda bilgilendirilmelidir.

\section{Kaynaklar}

1. Cooper DS. Subclinical hypothyroidism. N Engl J Med. 2001; 345(4): 260-5

2. Türkiye Endokrinoloji ve Metabolizma Derneği, tiroid hastalıkları tanı ve tedavi klavuzu. Subklinik hipotiroidi. 4. Baskı. Tuna matbacilık, Ankara, 2013, 13-15.

3. Surks MI, Hollowell JG. Age-specific distribution of serum thyrotropin and antithyroid antibodies in the US population: implications for the prevalence of subclinical hypothyroidism. J Clin Endocrinol Metab. 2007; 92(12): 4575.

4. Singer PA, Cooper DS, Levy EG, Ladenson PW, Braverman LE, Daniels G, Greenspan FS, McDougall IR, Nikolai TF. Treatment guidelines for patients with hyperthyroidism and hypothyroidism. Standards of Care Committee, American Thyroid Association. 1995; 273: 808-12.
5. Baskin HJ, Cobin RH, Duick DS, Gharib H, Guttler RB, Kaplan MM, Segal RL. American Association of Clinical Endocrinologists medical guidelines for clinical practice fort he evaluation and treatment of hyperthyroidism and hypothyroidism. Endocr Pract 2002; 8: 457-69.

6. Gharib H, Tuttle RM, Baskin HJ, Fish LH, Singer PA, McDermott MT; American Association of Clinical Endocrinologists/American Thyroid Association/Endocrine Society. Subclinical thyroid dysfunction: a joint statement on management from the American Association of Clinical Endocrinologists, the American Thyroid Association, and the Endocrine Society. Endocr Pract. 2004; 10(6): 497-501.

7. Fatourechi V, Klee GG, Grebe SK, Bahn RS, Brennan MD, Hay ID, McIver B, Morris JC 3rd. Effects of reducing the upper limit of normal TSH values. JAMA. 2003; 290(24): 3195-6.

8. Vanderpump MP1, Tunbridge WM, French JM, Appleton D, Bates D, Clark F, Grimley Evans J, Hasan DM, Rodgers H, Tunbridge $\mathrm{F}$, et al. The incidence of thyroid disorders in the community: a twenty-year follow-up of the Whickham Survey. Clin Endocrinol (Oxf). 1995; 43(1): 55-68.

9. Hollowell JG1, Staehling NW, Flanders WD, Hannon WH, Gunter EW, Spencer CA, Braverman LE. Serum TSH, T(4), and thyroid antibodies in the United States population (1988 to 1994): National Health and Nutrition Examination Survey (NHANES III). J Clin Endocrinol Metab. 2002; 87(2): 489-99.

10. Canaris GJ1, Manowitz NR, Mayor G, Ridgway EC. The Colorado thyroid disease prevalence study. Arch Intern Med. 2000; 160(4): 526-34

11. Hamburger JI, Meier DA, Szpunar WE. Factitious elevation of thyrotopin in euthyroid patients. N Engl J Med. 1985; 313(4): 267-8.

12. Tunbridge WM, Harsoulis $\mathrm{P}$, Goolden AW. Thyroid function in patients treated with radioactive iodine for thyrotoxicosis. $\mathrm{Br}$ Med J. 1974; 3(5923): 89-92.

13. Türkiye Endokrinoloji ve Metabolizma Derneği, tiroid hastalıkları tanı ve tedavi klavuzu. Tiroiditler. 4.baskı. Tuna matbac1lık, Ankara, 2013, 38-44.

14. Clinical guideline, part 1 . Screening for thyroid disease. American College of Physicians. Ann Intern Med. 1998; 129(2): 141.

15. Garber JR, Cobin RH, Gharib H, Hennessey JV, Klein I, Mechanick JI, Pessah-Pollack R, Singer PA, Woeber KA, American Association Of Clinical Endocrinologists And American Thyroid Association Taskforce On Hypothyroidism In Adults. Clinical practice guidelines for hypothyroidism in adults: cosponsored by the American Association of Clinical Endocrinologists and the American Thyroid Association. Thyroid. 2012; 22(12): 1200 .

16. Rugge JB, Bougatsos C, Chou R. Screening and treatment of thyroid dysfunction: an evidence review for the U.S. Preventive Services Task Force. Ann Intern Med. 2015; 162(1): 35.

17. Huber G, Staub JJ, Meier C, Mitrache C, Guglielmetti M, Huber P, Braverman LE. Prospective study of the spontaneous course of subclinical hypothyroidism: prognostic value of thyrotropin, thyroid reserve, and thyroid antibodies. J Clin Endocrinol Metab. 2002; 87(7): 3221-6.

18. Baumgartner C, Blum MR, Rodondi N. Subclinical hypothyroidism: summary of evidence in 2014. Swiss Med Wkly. 2014; 23: 144: w14058.

19. Meyerovitch J, Rotman-Pikielny P, Sherf M, Battat E, Levy Y, Surks MI. Serum thyrotropin measurements in the community: five-year follow-up in a large network of primary care physicians. Arch Intern Med. 2007; 167(14): 1533-8.

20. Hak AE, Pols HA, Visser TJ, Drexhage HA, Hofman A, Witteman JC. Subclinical hypothyroidism is an independent risk factor for atherosclerosis and myocardial infarction in elderly women: the Rotterdam Study. Ann Intern Med. 2000; 132(4): 270-8. 


\section{Ö.Ö. Gül, ark.}

21. Rodondi N, den Elzen WP, Bauer DC, Cappola AR, Razvi S, Walsh JP, Asvold BO, Iervasi G, Imaizumi M, Collet TH, Bremner A, Maisonneuve P, Sgarbi JA, Khaw KT, Vanderpump MP, Newman AB, Cornuz J, Franklyn JA, Westendorp RG, Vittinghoff E, Gussekloo J; Thyroid Studies Collaboration. Subclinical hypothyroidism and the risk of coronary heart disease and mortality. JAMA. 2010; 304(12): 1365-74.

22. Gencer B, Collet TH, Virgini V, Bauer DC, Gussekloo J, Cappola AR, Nanchen D, den Elzen WP, Balmer P, Luben RN, Iacoviello $\mathrm{M}$, Triggiani $\mathrm{V}$, Cornuz J, Newman $\mathrm{AB}$, Khaw KT, Jukema JW, Westendorp RG, Vittinghoff E, Aujesky D, Rodondi N; Thyroid Studies Collaboration. Subclinical thyroid dysfunction and the risk of heart failure events: an individual participant data analysis from 6 prospective cohorts. Circulation. 2012; 126(9): 1040-9.

23. Stagnaro-Green A, Roman SH, Cobin RH, el-Harazy E, Alvarez-Marfany M, Davies TF. Detection of at-risk pregnancy by means of highly sensitive assays for thyroid autoantibodies. JAMA. 1990; 264(11): 1422-5.

24. Casey BM, Dashe JS, Wells CE, McIntire DD, Byrd W, Leveno KJ, Cunningham FG. Subclinical hypothyroidism and pregnancy outcomes. Obstet Gynecol. 2005; 105(2): 239-45.

25. Monzani F, Del Guerra P, Caraccio N, Pruneti CA, Pucci E, Luisi M, Baschieri L. Subclinical hypothyroidism: neurobehavioral features and beneficial effect of L-thyroxine treatment. Clin Investig. 1993; 71(5): 367-71.

26. Joffe RT, Levitt AJ. Major depression and subclinical (grade 2) hypothyroidism. Psychoneuroendocrinology. 1992; 17(2-3): 215-21.

27. Roberts LM, Pattison H, Roalfe A, Franklyn J, Wilson S, Hobbs FD, et al. Is subclinical thyroid dysfunction in the elderly associated with depression or cognitive dysfunction? Ann Intern Med. 2006; 145(8): 573-81.

28. Chung GE, Kim D, Kim W, Yim JY, Park MJ, Kim YJ, Yoon $\mathrm{JH}$, Lee HS. Non-alcoholic fatty liver disease across the spectrum of hypothyroidism. J Hepatol. 2012; 57(1): 150-6.

29. Waring AC, Arnold AM, Newman AB, BùzkováP, Hirsch C, Cappola AR. Longitudinal changes in thyroid function in the oldest old and survival: the cardiovascular health study all-stars study. J Clin Endocrinol Metab. 2012; 97(11): 3944-50.

30. Fox CS, Pencina MJ, D'Agostino RB, Murabito JM, Seely EW, Pearce EN, Vasan RS. Relations of thyroid function to body weight: cross-sectional and longitudinal observations in a community-based sample. Arch Intern Med. 2008; 168(6): 58792.

31. Manji N, Boelaert K, Sheppard MC, Holder RL, Gough SC, Franklyn JA. Lack of association between serum TSH or free T4 and body mass index in euthyroid subjects. Clin Endocrinol (Oxf). 2006; 64(2): 125-8.

32. Tan ZS, Beiser A, Vasan RS, Au R, Auerbach S, Kiel DP, Wolf PA, Seshadri S. Thyroid function and the risk of Alzheimer disease: the Framingham Study. Arch Intern Med. 2008; 168(14): 1514-20.

33. Laukkarinen J, Kiudelis G, Lempinen M, Räty S, Pelli H, Sand J, Kemppainen E, Haglund C, Nordback I. Increased prevalence of subclinical hypothyroidism in common bile duct stone patients. J Clin Endocrinol Metab. 2007; 92(11): 4260-4.

34. Cinemre H, Bilir C, Gokosmanoglu F, Bahcebasi T. Hematologic effects of levothyroxine in iron-deficient subclinical hypothyroid patients: a randomized, double-blind, controlled study. J Clin Endocrinol Metab. 2009; 94(1): 151-6.

35. Jaeschke R, Guyatt G, Gerstein H, Patterson C, Molloy W, Cook D, Harper S, Griffith L, Carbotte R. Does treatment with L-thyroxine influence health status in middle-aged and older adults with subclinical hypothyroidism? J Gen Intern Med. 1996; 11(12): 744-9.

36. Mooradian AD. Subclinical hypothyroidism in the elderly: to treat or not to treat? Am J Ther. 2011; 18(6): 477-86.

37. Danese MD, Ladenson PW, Meinert CL, Powe NR. Clinical review 115: effect of thyroxine therapy on serum lipoproteins in patients with mild thyroid failure: a quantitative review of the literature. J Clin Endocrinol Metab. 2000; 85(9): 2993-3001.

38. Villar HC, Saconato H, Valente O, Atallah AN. Thyroid hormone replacement for subclinical hypothyroidism. Cochrane Database Syst Rev. 2007; 3: CD003419. 